\title{
KONFLIK TERBENTUKNYA NEGARA ISRAEL PADA TAHUN 1948-1973
}

\author{
Syahrul Adhim ${ }^{1}$, Yuliati ${ }^{2}$ \\ ${ }^{1}$ Universitas Negeri Malang \\ syahruladhim645@gmail.com \\ ${ }^{2}$ Universitas Negeri Malang \\ yuliati.fis@um.ac.id
}

\begin{abstract}
ABSTRAK
Tujuan penulis menulis artikel ini adalah, memaparkan bagaimana sejarah mengenai konflik berdirinya atau terbentuknya sebuah negara. Mengenai pembahasan yang akan dibahas dalam artikel ini adalah, konflik yang mengakibatkan sebuah peperangan dalam terbentuknya atau berdirinya Negara Israel di dalam sekitar lingkup wilayah negaranegara Arab termasuk wilayah Palestina. Kemudian, mengenai metode penelitian yang akan digunakan dalam menulis artikel ini adalah menggunakan cara library research dimana, dalam penulisan artikel ini dilakukan dengan mencari sumber rujukan dari jurnal, buku, dan karya ilmiah berdasarkan sesuai judul yang akan dikaji dalam artikel ini. Kemudian hasil pembahasan dari artikel ini mengungkap sejarah berdirinya Negara Israel terjadi karena perebutan kekuasaan wilayah kembali atas kejayaan suatu bangsa leluhur di masa lalu, hingga akhirnya suatu bangsa yang mempunyai peradaban leluhur di masa lalu ingin untuk menguasai tempat itu kembali. Seperti contoh Bangsa Yahudi menginginkan berdirinya sebuah negara yaitu Negara Israel. Bangsa tersebut menguasai wilayah daratan Palestina secara perlahan demi perlahan, hingga akhirnya terbentuklah berdirinya Negara Israel pada tahun 1948 sampai mengakibatkan peperangan yang hebat dengan negara-negara yang berbangsa Arab di sekelilingnya, peperangan tersebut berakhir pada Tahun 1973 dan dilakukan perjanjian secara damai.
\end{abstract}

Kata kunci: Negara Israel, Palestina, Konflik, Peperangan

\begin{abstract}
The author's aim in writing this article is to describe how the history of conflict is about the establishment or formation of a country. Regarding the discussion to be discussed in
\end{abstract}


this article, the conflict that resulted in a war in the formation or establishment of the State of Israel within the territory of Arab countries including the Palestinian territories. Then, regarding the research method that will be used in writing this article is to use method library research where, in writing this article, it is done by looking for reference sources from journals, books, and scientific papers based on the title to be studied in this article. Then the results of the discussion of this article reveal that the history of the establishment of the State of Israel occurred because of the struggle for territorial power again over the glory of an ancestral nation in the past, until finally a nation that had an ancestral civilization in the past wanted to control the place again. For example, the Jewish nation wants the establishment of a state, namely the State of Israel. The nation controlled the Palestinian mainland slowly by slowly, until finally the establishment of the State of Israel in 1948 resulted in a great war with the Arab nations around it, the war ended in 1973 and a peaceful agreement was made.

Keywords: State of Israel, Palestine, Conflict, War

\section{PENDAHULUAN}

Konflik suatu terbentuknya sebuah negara di dunia menjadikan hal yang biasa pada setiap wilayah dipenjuru benua di bumi ini, terlebih-lebih mengenai konflik yang berada di wilayah Asia Barat (Timur Tengah) atau di Jazirah arab. Pada kali ini pembahasan artikel difokuskan pada konflik terbentuknya negara Israel. Keinginan dengan adanya pendirian negara Israel, tak lepas dari bagaimana sejarah bangsa-bangsa terdahulu yang juga menguasai di daerah sekitar wilayah Palestina kuno seperti Bangsa Philistines atau Filistina kuno, Bangsa Assyria, Bangsa Babylon Bangsa Yunani, dan Bangsa Romawi sehingga, pada tahun 700 SM Bangsa Yahudi terusir dari tanah mereka sendiri dan mengungsi di wilayahwilayah Eropa dan Wilayah Mesopotamia (wilayah yang dikenal Irak sekarang pada masa peradaban kuno).

Selain itu di era selanjutnya disusul pula Bangsa Arab, Bangsa Turki Ottoman, dan Bangsa Eropa juga menguasai wilayah tersebut. Kemudian mengenai adanya teori yang dikemukakan bahwa, suatu konflik akan muncul dua atau lebih orang atau kelompok memiliki keinginan atau tujuan yang saling bertentangan maka kedua belah pihak tersebut pun telah memperebutkan wilayah ini (Palestina) dengan cara peperangan (Kriesberg: 1998). Disamping itu, faktor perebutan wilayah tersebut dalam sepanjang sejarah sering diceritakan dalam sejarah karena, lokasi tersebut yang strategis dalam jalur sutera darat di wilayah Asia Barat pada zaman kuno. Selanjutnya jika dilihat dari secara geografis, kewilayahan sejarah pendirian Kerajaan Israel kuno tepatnya pada 1000-800 SM terletak di antara Jazirah Sinai di selatan dan Pegunungan Lebanon di utara, antara Laut Tengah atau Laut Mediterania di bagian barat, dan wilayah sekitar 
gurun pasir Arab di bagian timur. Kemudian pada masa selanjutnya tepatnya pada masa abad ke 20, terjadi pembentukan gerakan Zionisme dimana, pada gerakan ini Bangsa Yahudi di Eropa merencanakan untuk menguasai wilayah tanah leluhur mereka yang sudah lama mereka lama tinggalkan. Sehingga bangsa Eropa berketurunan yahudi membentuk suatu organisasi yang bernama Jewish National Fund pada tahun 1901.

Setelah berlamanya waktu orang-orang Yahudi di Eropa terbantu untuk mewujudkan penguasaan tanah-tanah di Palestina sebagai pemukiman koloni orang-orang imigran Yahudi di Eropa dan kemudian dijadikan sebuah negara yang dinamakan Israel. Karena adanya Deklarasi Blafaour dimana pada isi deklarasi ini terdapat penguasaan terhadap wilyah-wilayah kekuasaan negara Blok Sentral pada Perang Dunia I sehingga, pada akhir perang wilayah dari pihak yang kalah (Blok Sentral) dari Perang Dunia I tersebut dikuasai sementara oleh sekutu (Inggris) termasuk Palestina kemudian dijadikan wilayah Mandat Ingrris. Hingga, pada masa Perang Dunia II imigran Yahudi Eropa melakukan eksodus besar-besaran dari Eropa ke Palestina dan pada puncaknya pada 1948 orang-orang Yahudi tersebut mendeklarasikan berdirinya Negara Israel yang kemudian memicu konflik antar negara-negara Arab di sekelilingnya sehingga menimbulkan peperangan terhdap berdirinya Negara Israel antara tahun 19481973.

\section{METODE PENELITIAN}

Mengenai metode penelitan pada pembuatan aritkel ini adalah, dilakukan secara library research atau penelitian kepustakaan. Dengan cara metode library research atau penelitian kepustakaan, penelitan ini dilakukan dengan mencari informasi mengenai sumber-sumber referensi yang cocok dengan penulisan judul artikel dan dengan hasil yang akan dibahas. Mengenai sumber-sumber informasi tersebut, didapat dalam berupa buku, jurnal dan artikel, dokumen tertulis, dan karya ilmiah baik berupan online maupun tidak. Kemudian sumber-sumber referensi tersebut dibaca, dianalisa, dan disimpulkan secara teliti dan cermat sehingga, mendapatkan hasil pembahasan yang maksimal.

\section{HASIL DAN PEMBAHASAN}

Mengenai hasil pembahasan yang sudah dianalisis dari pencarian sumbersumber kepustakaan telah didapati bahwasanya, jika suatu terbentuknya negara maka tejadilah konflik yang mengakibatkan klaim persengketaan hagemoni bangsa terdahulu mengenai pembentukan sebuah negaera tak lepas dari sejarah masa lalu yang menceritakan bahwa bangsa pendahulunya tersebut telah menepati tempat itu kemudian berpindah tempat dikarenakan peperangan dan pengusiran besar-besaran. Sehingga suatu konflik akan muncul dua atau lebih 
orang atau kelompok memiliki keinginan atau tujuan yang saling bertentangan maka kedua belah pihak tersebut pun telah memperebutkan wilayah tersebut.

Begitu pula dengan konflik mengenai terbentuknya Negara Israel, Negara Israel secara historis merupkan bangsa kuno yang tinggal di wilyah daratan sekitar wilyah palestina kuno dan disana Bangsa Israel mendirikan kerajaan Israel pada 1000 SM. Namun ketika Bangsa asing mau menjajah daratan palestina, bangsa Isreal yang kebanyakan terdiri dari kaum orang-orang dari Bangsa Yahudi mengungsi ke wilayah Eropa dan wilayah Timur Tengah lainya, termasuk Mesopotamia (wilayah yang dikenal Irak sekarang pada masa peradaban kuno). Sehingga sampai sekian lamanya bangsa Israel Yahudi menjadi bangsa yang pudar keaslianya dan menjadi bangsa yang berbaur dan bercampur dengan bangsa-bangsa lain pada masa pengasingan yang amat begitu lama.

Kemudian mengenai sejarah awal mula orang-orang Yahudi di Eropa yang mau menguasai wilyah mereka yang dahulunya sudah lama ditinggalkan didasari oleh alasan atau sebab umum, tepatnya pada abda ke-19, Ottoman atau yang dikenal Kekhilafahan Utsmaniyah melakukan kerjasama dengan bangsa Eropa untuk meningkatkan perekonomian Ottoman. Kemudian pada kesempatan ini digunaka oleh Bangsa Yahudi keturunan Israel-Eropa yang ada di Eropa melakukan pembujukan terhadap negara di Eropa untuk kembali ke tanah asli leluhur mereka yang telah lama ditinggalkan yaitu, tanah Palestina yang kemudian dipercayai bahwasanya wilayah tersebut merupakan wilayah yang dijanjikan oleh tuhan mereka yang dikenal dalam Bahasa Ibrani Eretz Israel.

Dengan siasat ini, para Bangsa Yahudi di Eropa merencanakan untuk menduduki wilayah tersebut dengan membeli tanah-tanah kosong diwilayah itu dan bangsa Yahudi di Eropa menyadari bawasanya tanah di Palestina merupaka wilyah terpenting demi masa depan keberlangsungan pendirian Negara Israel yang akan mereka dirikan. Dan utuk keberlangsungan rencana itu, para orangorang Yahudi Eropa medirikan sebuah organisasi yang bernama bernama Jewish National Fund atau yang bisa disebut "Dana Nasional Yahudi" yang kemudian dipergunakan untuk pusat penkoordinasian dan penginformasian mengenai pembelian tanah-tanah kosong di Palestina yang kala itu dalam kekuasaan otoritas Ottoman.

Sehingga dengan siasat ini para Yahudi di Eropa bisa memastikan kapan untuk membeli tanah tersebut tanpa memancing kecurigaan otoritas Daulah Kekhalifahan Ottoman/Utsmaniyah akan tetapi dengan syarat, bahwa tanah yang sudah dibeli oleh orang Yahudi tersebut tidak akan pernah dijual kepada siapapun. Sehingga pada akhirnya bangsa Yahudi di Eropa sangat leluasa dan melakukan eksodus dari Eropa ke Palestina dan membentuk pemukiman disana. Dan pada sekitar tahun 1895-1914 puluhan ribu orang Yahudi dari Eropa berhasil memasuki wilayah daratan Palestina dengan dalih bukan alasan 
mengenai agama akan tetapi, mendirikan sebuah koloni dan basis pangkalan untuk menguasai tanah-tanah di wilayah Palestina dan dijadikan sebagai Negara Israel.

Selang berlamanya waktu, bangsa Arab di Palestina sangat curiga dengan adanya banyak sekali orang-orang Yahudi di Eropa melakukan eksodus besrarbesaran dari Eropa ke Palestina. Hal ini semakin menyakinkanya penduduk Arab di Palestina sangat khawatir mengnai bertambah banyaknya orang Yahudi masuk ke welayah mereka dan suatu saat akan menjadi ancman besar bagi Bangsa Arab dan penduduk Arab di Palestina.

Saat menjelang permulaan Perang Dunia I Turki yang kala itu Ottoman atau Kesultanan Utsmaniyah bersekutu dengan Kekaisaran Jerman sehingga pada situasi seperti ini, Inggris takut dan khawatir atas bergabungnya Turki Ottoman dengan Kekaisaran Jerman yang menjadi aliansi Blok Sentral, kemudian Inggris meminta bantuan Yahudi yang ada di Eropa. Sehingga Inggris percaya bantuan Yahudi di Eropa terhadap Zionis akan membawa Yahudi di Amerika juga untuk mendorong presiden Amerika Serikat kala itu Woodrow Wilson agar mau bersekitu dengan Inggris, sehingga Inggris membetuk Deklarasi Blafaour pada tanggal 2 November 1917 dimana, isi perjanjian tersebut digunakan untuk menjajikan kampung halaman bagi Bangsa Yahudi untuk menduduki wilayah Palestina dan dijadiakan sebagai pemukiman koloni orang-orang Yahudi.

Setelah berakhirnya Perang Dunia I kemenangan pihak sekutu yaitu di pihak Inggris dan juga LBB (Liga Bangsa-Bangsa) membentuk suatu mandat mengenai teritori khususnya untuk daerah yang penah dikuasai Kekaisaran Jerman dan Turki Ottoman. Dengan sistem mandat tersebut teritori yang pada mulanya dikuasai oleh Kekaisaran Jerman dan Turki Ottoman, kemudian berpindah tangan untuk semntara dikuasai oleh pihak sekutu (Inggris) sebagai pemenang perang, termasuk juga wilayah Palestina yang kemudian masuk kedalam hagemoni Inggris. Setelah masuknya Palestina kedalam hagemoni Inggris, Inggris kemudian menjajikan tanah yang akan dijanjikan kepada orang-orang Yahudi, dimana tanah yang telah dijanjikan akan didirikan sebuah negara yang bernama Israel. Walaupun juga orang-orang Arab di Palestina juga mentukan nasib sendiri untuk mendirikan negara akan tetapi, Inggris juga menolak dengan atas dasar pertimbangan apa yang sudah dijalanninya dalam Deklarasi Blafaour tersebut.

Dengan adanya Deklarasi Blafaour, maka semakin mulus dan mudahnya bagi orang-orang Yahudi untuk mendirikan Negara Israel di Palestina semenjak pasca Perang Dunia I. Kemudian setelah Perang Dunia I orang-orang Yahudi di Eropa berimigrasi ke wilayah Palestina ditambah pula Yahudi dari Timur Tengah sendiri, dan hal ini seakan menjadi-jadi di setiap tahunya bahkan, orang-orang Yahudi semakin intens memasuki wilayah Palestina. Dengan semakin intensnya 
orang-orang Yahudi masuk ke Palestina, hal tersebut juga menuai kecaman oleh penduduk Arab di Palestina mengenai semakin banyaknya orang-orang Yahudi masuk ke Palestina semakin meningkat pada setiap tahunya. Dan bukan hanya menuai kecaman terhadap imigran Yahudi, penduduk Arab di Palestina juga melakukan pemberontakan kepada orang-orang Yahudi dan Pemerintahan Inggris di Palestina.

Akan tetapi, pemberotakan yang dilakukan penduduk Arab Palestina tidak membuahkan hasil sama sekali. Dengan adanya dukungan dari Inggris para imigran Yahudi semakin melebarkan sayapnya untuk menguasai tanah-tanah di Palestina dan pada setiap tahunya orang-orang imigran Yahudi tersebut jumlahnya semakin meningkat dan semakin leluasa untuk membuat pemukiman koloni yang berisikan orang-orang Yahudi yang kemudian mendiami disana (Wilayah Palestina). Kemudian, pihak Inggris juga ikut campur tangan megenai permaslahan yang ada di wilayah Palestina yaitu, dengan rencana pemisahan wilayah teritori antara wilayah yang telah dimukimi atau ditinggali oleh orangorang imigran keturunan Bangsa Yahudi dari Eropa dan penduduk asli Bangsa Arab Palestina sendiri namun, rencan pemisahan tersebut ditolak oleh Arab Palestina yang bersikukuh untuk memiliki dan menguasai wilayah Palestina secara keseluruhan.

Pada saat Perang Dunia II berlangsung, kedatangan imigran orang-orang Yahudi di Eropa ke Palestina semakin banyak dan pemigkatanya semakin tajam serta, menambah kekhawatiran dan kerumitan permasalahan antara orang Yahudi dan Penduduk Arab Palestina. Hal ini dipicu karena di Eropa sendiri Hitler yang tekenal dengan Nazi-nya mengeklaim bahwasanya Bangsa ras Arya di Jerman lebih baik dari pada ras inferior ata ras rendahan seperti orangorang dari keturunan Bangsa Yahudi. Sehingga banyak sekali Yahudi di Eropa mengungsi di Palestina sehingga mebuat koloni dan membentuk pemukiman disana, hal ini juga memunculkan pemberontakan-pemberontakan terhadap imigran Yahudi Eropa dan menimbulkan sebuah krisis di Wilayah Palestina. Dan akhirnya untuk menagani krisis tersebut, Inggris menyerahkan Wilayah Palestina yang dulunya sebagai mandat, kemudian menyerahkan mandat Palestina kepada PBB (Perserikatan Bangsa-Bangsa) kemudian membentuk sebuah organisai yang disebut UNSCOP (United Nation Special Comitte on Palestine) dimana, organisasi ini dibentuk untuk mengentaskan permasalahan antara penduduk Arab Palestina dengan penduduk imigran Yahudi Eropa yang bermukim (berkoloni) di Palestina.

Kemudian pada 1947 atas usulan UNSCOP bahwasanya menyarankan wilayah tersebut rencananya dibagi menjadi dua wilayah yaitu, wilayah satu untuk penduduk Arab Palestina dan wilayah dua untuk penduduk Yahudi. Namun penduduk Arab Paletsina dan negara-negara Arab lainya tidak ada yang setuju 
dengan usulan mengenai rencana pemisahan wilayah ini. Dan hal tersebut sudah ditentang oleh bangsa seluruh wilayah Arab termasuk Bangsa Arab yang ada di Palestina dan yakin apabila rencana tersebut benar-benar diterima maka hal yang benar-benar akan yang terjadi adalah, orang-orang keturunan Bani Israel atau Yahudi akan mendirikan dan mendapat legitimasi yang sah mengenai pendirian negara Israel di tanah Palestina, dan akhirnya orang-orang Yahudi imigran dari Eropa mengambil langkah yang sangat amat berani yaitu, tepatnya pada tanggal 14 Mei 1948 di Tel Aviv mendeklarasikan Negara Israel dengan batas wilayah teritorinya dengan David Ben Gurion sebagai pememimpin orang-orang Yahudi sekaligus pemimpin pertama kemerdekaan Negara Israel. Kemudian setelah selang satu hari setelah Israel mendeklarasikan kemerdekaanya, tepatnya tanggal 15 Mei 1948 Amerika juga mengakui kedaulatan terbentuknya Negara Israel secara de facto dan disusul Uni Soviet mengakui kedaulatan Negara Israel secara de jure, dan dipertepatan hari yang sama negara-negara Arab mulai menginvasi Negara Israel yang berdiri di tanah Palestina sehingga, hal ini membuka babak baru sejarah peperangan di Timur tengah (Asia Barat).

Dan dari keseluruhan peristiwa tersebut, terbentuklah konflik antara Palestina dan Israel, hal ini didasari karena sebelum berdirinya negara Israel, terdapat sebuah adanya rencana pemisahan wilayah di Palestina oleh PBB dalam organisai yang dibentuk (UNSCOP) 1947 dan pembentukan Negara Israel pada tahun 1948. Seketika itu negara-negara diwilayah Arab seperti Irak, Syria, Lebanon Mesir, dan Jordania melakukan penyerbuan ke Palestina pada tahun 1948. Pada tahun tersebut terjadi dua gelombang perag yang bersekala besar yang pertama, dimulai dari pertengahan Mei-11 Juni 1948, kemudian perang kedua berlangsung pada 6-19 Juli 1948, hingga dengan adanya gencatan senjata pada tahun 1949.

Akibat konflik yang berkepanjangan ini, perang besar selanjutnya terbentuk dari tahun 1956, 1967, dan 1973. Pertama pada tahun 1956 terjadi perang anatara Mesir dengan Israel di terusan Suez atau bisa disebut Perang Suez. Perang tersebut dikarenakan Mesir gagal dan tidak mampu untuk membela nasib Palestina sehingga, pada perang tersebut memicu kapal-kapal yang menuju Israel memasuki terusan Suez tidak di izinkan masuk hingga akhirnya, akibat tindakaan Mesir negara Eropa seperti Inggris dan Prancis dirugikan dikarenakan Mesir telah menghalangi jalur perdagangan dua negara tersebut, hal tersebut juga dirasakan oleh Israel yang sama-sama merugi di karenakan jalur pelayarannya terhambat atau terhalang karena sebuah konflik, dan pada saat itulah Israel meminta bantuan Prancis dan Inggris untuk mengakhiri peperangan, selain itu pihak dari Amerika Serikat juga turun tangan untuk menghentikan konflik peperangan tersebut dan akhirnya, tepatnya pada tahun 1957 Israel, Inggris dan Prancis meenarik mundur masing-masing serdadu pasukanya untuk mundur, 
dan selama pada masa ini sampai masuknya tahun1960-an pula, terbentuklah organisasi yang bernama PLO (Palestine Liberation Organization) atau Orgnisasi Pembebasan Palestina

Kedua, Perang Enam Hari atau The Sixs-Day War 1967. Perang ini mengakibatkan berkonfrontasikannya Israel dengan melawan dua Negara koalisi Arab Yaitu, Mesir dan Syria tepatnya di wilayah Semenanjung Sinai. Perang ini dipicu oleh inflitrasi Fatah terhadap Israel, dan Israel sendiri merasa bahwa adanya ancaman dukungan Syiria terhadap Palestina, kemudian Israel memutuskan melakukan serangan balasan terhadap Syria, walaupun Syria mendapat dukungan dari Mesir, akhirnya Syira sudah tidak sanggup menangani serangan Israel tersebut, dan pada akhirnya pasukan Israel menduduki wilayah Semenanjung Sinai, Tepi Barat Jalur Gaza, dan Dataran Tinggi Golan, hingga Dewan Keamana PBB juga ikut turuntangan dalam mengakhiri peperangan tersebut dengan mengeluarkan peraturan resolusi No. 242 yang berisikan penarikan mundur pasukan Israel dari wilayah yang diduduki, menghendaki dan memberikan kehormatan atas hak-hak kemerdekaan kedaulatan negaranegara Arab di Timur Tengah sehingga terciptalah kehidupan yang damai tanpa peperangan.

Terakhir, pada tahun 1973 terjadi peperangan besar yang terakhir dalam sejarah konflik berdirinya atau terbentuknya Negara Israel di Wilayah Palestina adalah, perlawanan antara Israel, dengan koalisi Negara Arab yaitu, Mesir dan Syria. perang ini dinamakan perang Yom Kippur dikarenakan betepatan dengan hari suci orang Yahydi. Pada perang ini terjadi karena rasa kekhawatiran negaranegara Arab atas keberadaan pemukiman orang-orang Yahudi di Israel semakin meningkat dan semakin menjadi-jadi. Dan pada akhirnya Israel memenangkan perang ketiga tersebut atas Mesir dan Syria dan hal ini PBB juga ikut campur tangan lagi mengnai penyelesai konflik tersebut sehingga PBB mengeluarkan resolusi baru yaitu, No. 338 dan mengadakan negosiasi perdamaian antara negara yang berkonflik berdasarkan resolusi sebelumnya yaitu resolusi No. 242 .

\section{PENUTUP}

Secara kesimpulan mengnai konflik terbentuknya Negara Israel adalah mengenai adanya sejarah masa lalu khususnya sejarah bangsa Yahudi atau Bani Israil pda masa kuno, tepatnya pada 1000-700 SM dimana pada masa ini terbentuknya sebuah kerajaan yang berisikan orang-orang dari Bangsa Yahudi yang mendiami di sekitar wilayah daratan Palestina Kuno hingga pada akhirnya bangsa Yahudi terusir dari tanah leluhurnya dikarenakan wilayahnya sering dijadikan perebutan kekusaan bangsa lain. Sehingga orang-orang Yahudi tersebut berpencar dan mengungsi di wilayah seperti Eropa dan beberapa di daerah sekitan Timur Tengah. 
Hingga pada masa yang baru, orang-orang Yahudi yang sudah berpencar dan tersebar di penjuru wilayah Eropa menginginkan terbentuknya sebuah Negara Yahudi dimana, negara ini yang orang-orang Yahudi ciptakan sejak lama, kemudian sekian lamanya waktu orang-orang Yahudi melakukan gerakan Zionisme dimana untuk menguasai tanah leluhur meraka dahulu.

Pada masa akhir Perang Dunia I kemenangan pihak sekutu menjadikan beberapa wilayah yang dulunya milik pihak Blok Sentral dikuasai oleh sekutu, salah satunya wilayah Palestina sehingga sekutu (Inggris) membuat Deklarasi Balfaour dan membentuk mandat terhadap penguasaan Paletina dan dari mandat tersebut menjadikan orang-orang Yahudi untuk memuluskan tujuanya mendirikan Negara Israel dengan siasat membeli tanah kosong di Palestina dan mendiami wilayah tersebut untuk membuat koloni pemukiman. Dan pada akhirnya terjadi Ekodus besar-besaran orang Yahudi dari Eropa serta gerakan ini juga memancing kelompok Yahudi lain dari beberapa wilayah di Timur tengah untuk pindah ke Palestina, dan pada masa ini tepatnya pada awal Perang Dunia II sampai akhir, imigran Oarng Yahudi dari Eropa semakin menjadi-jadi dan semakin banyak setiap tahunya sehingga menjadikan rasa kekhawatiran bagi Bangsa Arab yang tinggal di sekitar wilayah tersebut.

Hingga pada akhirnya, pada tahun 1948 berdirilah dan dideklarasikanya Negara Israel beserta wilayah teritorinya dengan David Ben Gurion sebagai pemimpn kemerdekaan Negara Israel. Kemudian dikarenakan ulah dari pendudukan orang-orang Yahudi di Palestina yang telah membentuk dan mendeklarasi sebagai Negara yang bernama Israel sehingga, memicu kemurkaan negara-negara Arab dan bangsa-bangsa Arab disekitarnya dan memulai untuk perang terhadap pembentukan Negara Israel di Palestina hingga, perang tersebut berakhir pada tahun 1973 dengan perjanjian damai. 


\section{DAFTAR PUSTAKA}

A, Alfian Nurtsabit. (2013). Kajian Tentang Nasionalisasi Terusan Suez Dan Kepentingan Negara-Negara Barat (1956-1957). Skripsi. Universitas Negeri Yogyakarta.

Daldjoeni, N. (2019). Geografi Kesejarahan 1 Peradaban Dunia. Yogyakarta: Penerbit Ombak.

Hamli, Moh. (2013.) Konflik Israel Palestina Kajian Historis Atas Kasus Perebutan Tanah Antara Israel Dan Palestina 1920-1993. Skripsi. Universitas Islam Sunan Kalijaga.

Masyarofah. (2015). Fakta Perjanjian Damai Dan Hubungan Politik Diplomatik Negara Timur Tengah Dalam Proses Perdamaian Konflik Israel-Palestina Pasca Kemerdekaan Palestina. Salam: Jurnal Sosial dan Budaya Syar'i, 2 (1), 82-102.

Muchsin, Misri A. (2015). Palestian Dan Israel: Sejarah Konflik, dan Masa Depan, MIQOT, XXXIX (2), 390-406.

Nurjanah, Emilia Palupi M. \& Fakhrudin. (2019). Deklarasi Balfaour Awal Mula Konflik Israel Palestina. PERIODE: Jurnal Sejarah dan Pendidikan Sejarah, 1 (1), 15-26.

Ruslin, Ismah Tita. (2013). Memetakan Konflik Timur Tengah (Tinjauan Geografi Politik). Jurnal Politik Profetik, 1 (1), 1-23.

Satrianingsih, Andi, \& Zaenal Abidin. (2016). Sejarah Zionisme Dan Berdirinya Negara Israel. Jurnal Adabiyah, 16 (2), 172-185.

Syahroni, Danni. (2016). Perang Enam Hari (Suatu Kajian Historis Mengenai Kemenangan Militer Israel dalam Menghadapi Aliansi Arab Tahun 1967). Skripsi. Universitas Pendidkan Indonesia Bandung. 